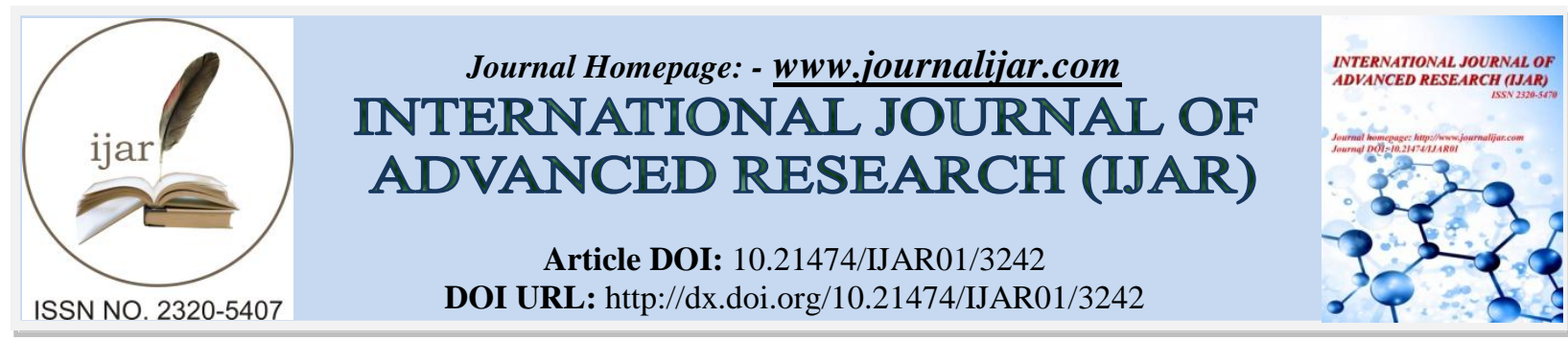

RESEARCH ARTICLE

\title{
SOLID WASTE DISPOSAL METHODS PRACTICED BY INHABITANTS OF A TYPICAL NIGERIAN RURAL COMMUNITY.
}

\author{
Enebechi Jude C. ${ }^{1}$ (PhD). And Ani Ngozi Rita. ${ }^{2}$ (PhD).
}

1. Department of Physical and Health Education, Enugu State College of Education (Technical), Enugu, Nigeria.

2. Department of Health and Physical Education, Enugu State University of Science and Technology (ESUT)Enugu. Nigeria.

\section{Manuscript Info}

Manuscript History

Received:21 December 2016

Final Accepted: 16 January 2017

Published: February 2017

Key words:-

Solid Waste, Practice, Inhabitants.

\begin{abstract}
Interactions between man and his environment have led to generation of wastes that pose problem of management and disposal. Failure to adopt appropriate disposal methods is followed by risk of infectious diseases. This study reports a survey involving a sample of 300 respondents drawn from a population of 3,427 rural inhabitants using the cluster sampling procedure. Two research questions were raised for the study that aimed to determine the solid waste disposal practices of typical Nigerian rural inhabitants. Instrument for data collection was the questionnaire designed by the researchers and contained 4 response options and used to elicit information from the respondents through interview schedule. Validity of the instruments was established through the judgment of three health educators and the reliability index value yielded 0.86 using the split half method and Spearman Brown correlation statistic. Data was analyzed on item-by-item basis using mean. It was found that the respondents disposed their refuse using all the refuse disposal methods highlighted by the researcher, but the once used very often by the rural inhabitants were open or uncontrolled burning, indiscriminate dumping on the ground and in the river. Implications of the practice for human health were articulated. The researchers recommended among other things that rural health extension workers should increase their enlightenment of the inhabitants on the need to adopt proper and suitable waste disposal methods.
\end{abstract}

Copy Right, IJAR, 2017,. All rights reserved.

\section{Introduction:-}

Management of wastes, especially, the solid type remains a cardinal element in the protection and promotion of public health. The continuous interaction between man and his physical, social and psychological environment has led to the generation of wastes that pose problem of management and disposal. This is followed by the risk of infectious diseases as a result of failure to adopt appropriate disposal methods. Waste according to Basavanthappa (2008) applies to unwanted or discarded waste matter. Also waste can be described as the unwanted solid-state materials originating from diverse environment. This means that waste is anything that is no longer useful and needs to be got rid of. The practice of getting rid of the wastes has been perceived as disposal (Basavanthappa, 2008, Park, 2011 and Obionu, 2015). Solid waste disposal therefore is the act of getting rid of solid-state materials that

Corresponding Author:- Ani Ngozi Rita. (PhD).

Address:- Department of Health and Physical Education, Enugu State University of Science and 971 
have been rejected as being useless and no longer wanted or needed. Suitable disposal methods are desired because of the variations in the types of waste generated in different places. This is evident in the views of Obionu (2015) who observed that a typical Nigerian solid waste could be classified into vegetable wastes; animal wastes; and mineral wastes. Consequently Otujo and Awokoya (2014) stated that one of the greatest threats to public health is improper disposal of waste, the presence of wastes poses serious health problems especially when such wastes are given less attention or left unattended to in terms proper disposal or management.

Similarly, methods adopted in the disposal of the wastes generated could also vary according to the locations. This is why it has become necessary that solid waste disposal methods adopted by the inhabitants of typical Nigerian rural community are determined. These unwanted solid-state materials are known to be disposable through various acceptable methods. Such methods according to different authorities (Akinsola, 2006, Lucas and Gilles, 2009 and Obionu,2015) are: controlled tipping; composting; incineration; berging; indiscriminate dumping; burying; pulverization; and recycling. Controlled tipping is the practice of pilling wastes at a place and covering them with sand daily as against indiscriminate dumping of wastes anywhere without control and care. While incineration is burning the wastes in a large container, compositing is heaping the wastes in a pit for months with periodic turning. Berging is dumping the wastes inside water body such as sea or river. Pulverization is crushing the wastes with intention of either to convert into useful materials or burying.

Nonetheless, a typical Nigerian rural community may be faced with the environmental challenges of solid waste disposal. Following the obvious consequences of not being on top of solid waste challenges as a result of adopting unsuitable waste disposal methods, the need to determine the methods practiced by inhabitants of a typical Nigerian rural community has become needful. Practice according to Hornby (2001) is a thing that is done regularly as custom or habit. In the present study the methods regularly adopted by rural inhabitants in the disposal of solid waste will be determined.

Focusing such studies more on the rural area of Nigeria where well over 80 percent of Nigerians live (Ezedum (2002),Ani and Ezeugwu, 2014) may even be more rewarding. Furthermore, the Federal Environmental Protection Agency (EPA) and the State Environmental Sanitation Authorities in Nigeria, appear to have their focus on urban areas, thereby neglecting the rural areas. For instance, the desired impact of the monthly environmental sanitation exercise is hardly extended to and felt in the rural areas. Also In a similar study by Ani and Ugwuoke (2015), they found that there was a low level of provision of human waste disposal facilities in the rural community where the study was conducted. This development leaves the inhabitants of rural areas with the potentiality of being exposed to waste disposal related infectious diseases.

One of such typical Nigerian rural communities is Obioma in Udi Local Government Area of Enugu State. The community is organized into five villages and nineteen wards with undulating topography and the majority of the inhabitants who may be made of female subsistent farmers sharing different levels of education and ages. Whether these characteristics of the community could influence the choice of disposal methods therein is yet to be determined by this study. It is in view of this that Obionu (2015) held that the choice of a method for disposal of refuse would depend on the physical characteristics of the locality such as topography, character and quantity of the waste. Be that as it may, the broad objectives of any waste disposal method are to eliminate hazard to man; to prevent pollution of natural environment and; to salvage materials of economic value (Lucas and Gills, 2009). For these desired objectives to be achieved, especially in a rural area of a developing country, appropriate disposal methods have to be adopted. This is why the researchers specifically intend to:

1) determine the solid waste disposal methods of the inhabitants of a typical Nigerian rural community

2) find out the solid waste disposal methods often used by the inhabitants of a typical Nigerian rural community

The following research questions guided the study

1) What are the solid waste disposal methods adopted by the inhabitants of a typical Nigerian rural community?

2) What solid waste disposal methods are often used by the inhabitants of a typical Nigerian rural community

\section{Methods:-}

The survey research design was adopted for the study. Three thousand four hundred and twenty seven $(3,427)$ inhabitants (NPC, 2007) of Obioma community formed the population for the study. Cluster sampling procedure was employed in drawing the sample. Each village of Aba, Ameke, Umunugwo, Oluku and Amachalla was regarded as a cluster. Six respondents were selected from each of the ten households that were purposively drawn from each 
cluster. The purpose was to control for the households that have up to six members with respondents' characteristics.

Instrument for data collection was a 16- item questionnaire with four response options. The respondents were required to indicate the disposal methods used and how often they dispose their solid wastes using the outlined methods of solid wastes disposal. Validity of the instrument was established through the judgment of three experts and the reliability for internal consistency was determined using test re-test method. The correlation coefficient index value yielded .86 using Spearman Brown correlation statistic .Data was collected personally by the researchers with the help of two research assistants, using interview schedule technique. Data collected from 300 inhabitants who responded to the questionnaire were analysed item-by-item using mean. The response options were assigned weights of 4, 3, 2, and 1 accordingly. Mean responses of 3.00-4.00 were regarded as strongly agree or very often; $2.00-2.99$ were regarded as agree or sometimes, $1.00-1.99$ were regarded as seldom or disagree while below one were regarded as never practiced or strongly disagree.

\section{Results:-}

Table 1:- Mean Responses of the Inhabitants' on Solid Waste Disposal Methods used

\begin{tabular}{|l|l|l|l|l|}
\hline $\mathbf{S} / \mathbf{N}$ & Waste Disposal Methods & $\mathbf{X}$ & $\mathbf{S D}$ & Interpretation \\
\hline 1 & Controlled Tipping & 2.14 & 1.02 & Agree \\
\hline 2 & Composting & 2.43 & 1.07 & Agree \\
\hline 3 & Open or uncontrolled Burning & 2.22 & 0.84 & Agree \\
\hline 4 & Berging or throwing inside river & 2.96 & 0.73 & Agree \\
\hline 5 & Indiscriminate Dumping & 3.00 & 0.98 & Strongly agree \\
\hline 6 & Burying & 2.52 & 0.89 & Agree \\
\hline 7 & Pulverization & 1.96 & 0.78 & Disagree \\
\hline 8 & Recycling & 1.88 & 0.72 & Disagree \\
9 & Incineration & 1.58 & 0.64 & Disagree \\
\hline & Grand Mean & $\mathbf{2 . 3 0}$ & $\mathbf{0 . 8 5}$ & Agree \\
\hline
\end{tabular}

Data in Table 1 show a grand mean score of 2.30 which indicates that inhabitants agree that they dispose their solid wastes. Data in the Table also reveal that item 5 attracted mean score of 3.00 meaning that the inhabitants strongly agree that they dispose their refuse indiscriminately. Also in the table, it was shown that the respondents agreed that they dispose their solid waste by control tipping, composting, open burning, berging and burying. However, the Table shows that items 7, 8 \& 9 attracted mean scores of $1.96,1.88 \& 1.58$ respectively. This implies that the inhabitants disagree with disposing their solid wastes by pulverization, recycling and incineration.

Table 2:- Mean Responses on Solid Waste Disposal Methods often used by the inhabitants of a typical Nigerian rural community

\begin{tabular}{|l|l|l|l|l|}
\hline S/N & Waste Disposal Methods & $\overline{\mathbf{X}}$ & $\mathbf{S D}$ & Interpretation \\
\hline 1 & Controlled Tipping & 1.62 & 1.02 & Sometimes \\
\hline 2 & Composting & 2.14 & 1.07 & Sometimes \\
\hline 3 & Incineration & 2.22 & 0.84 & Sometimes \\
\hline 4 & Bergin or throwing inside river & 3.16 & 0.73 & Very often \\
\hline 5 & Indiscriminate Dumping & 3.46 & 0.98 & Very often \\
\hline 6 & Burying & 2.52 & 0.89 & Sometimes \\
\hline 7 & Pulverization & 1.16 & 0.78 & Never \\
\hline 8 & Recycling & 1.38 & 0.72 & Never \\
9 & Incineration & 1.25 & 0.42 & Never \\
\hline & Grand Mean & $\mathbf{2 . 1 0}$ & $\mathbf{0 . 8 8}$ & Sometimes \\
\hline
\end{tabular}

Data in Table 2 show a grand mean score of 2.10 which indicates that inhabitants sometimes dispose their solid wastes. Data in the Table also reveal that items 4 and 5 attracted mean scores of 3.16 and 3.46 meaning that the inhabitants practice throwing of waste inside river and indiscriminate dumping of refuse very often. Also in the table, it was shown that the respondents sometimes dispose solid waste by control tipping, incineration, composting and burying. However, the Table shows that items $7.8 \& 9$ attracted mean scores of $1.16,1.38 \& 1.25$ respectively. 
This implies that the inhabitants never practiced pulverization, recycling and incineration as methods of disposing their solid wastes.

\section{Summary of Findings:-}

1. Rural inhabitants agreed that they dispose their wastes

2. Waste disposal practices often adopted by rural inhabitants were mainly indiscriminate dumping on the ground and sea, burying and open burning.

\section{Discussion:-}

The purpose of this study was to determine the solid waste disposal methods of the inhabitants of a typical Nigerian rural community. The findings showed that typical Nigerian rural inhabitants dispose their solid wastes by mainly dumping them indiscriminately, burning them, throwing inside river or sometimes burying. A typical Nigerian solid waste is composed of leaves, food items, paper, cartons, rags, plastic and polythene, tins, broken bottles and glasses (Obionu, 2015). Majority of them are dry refuse which may promote fire disaster if not properly disposed. Given this background of the methods adopted by rural inhabitants, exposure to health hazards of enormous dimension is highly imminent. This is because it has been warned that indiscriminate dumping of refuse would lead to fire outbreak and injuries, especially to children playing around and also cause flooding by blocking drainage channels.

In addition to these, it is known that improper solid waste disposal would lead to offensive conditions such as bad smells, fly mosquito breeding and proliferation of other hazardous vectors and vermin. However, the finding that these rural inhabitants dispose waste indiscriminately was not surprising to the researcher. This is because, Akinsola (2006) had earlier observed that uncontrolled dumping of waste was commonly used in rural tropical communities where there was either no facility for proper disposal or that control measures were lacking, however it is not a positive development because it is expected that their ought to be an improvement in the waste disposal practices of the people going by the efforts on the ground by various health and environmental agencies in ensuring that there is improved environmental sanitation in Nigeria.

The implication of the finding is that, the objective of eliminating hazard to man; and preventing pollution of natural environment through proper waste disposal would become a mirage in the rural communities. Furthermore, poor sanitary environmental-related diseases will be promoted and optimal health status may reduce. This finding is in agreement with Lucas and Gilles (2009), Otujo and Awokoya (2014) who had observed that failure to manage and dispose waste properly exposed people to increased risk of infectious disease. It is the suspicion of the researchers that, the burying that is sometimes practiced by the inhabitants is limited to the disposal of the dead. Disposing the dead by burying is a generally adopted method especially among the Christians and Moslems. The burning found to be practiced by these inhabitants is generally seen as having its demerits. Apart from the danger of disease spread, it contributes to ozone layer depletion, atmospheric pollution, and global warming; hence there is need for improved waste disposal practices by the rural dwellers.

\section{Conclusion:-}

Based on the findings of the study, the following conclusions are made:

(1) Rural inhabitants dispose their solid waste.

(2) Solid waste disposal practices of rural inhabitants are indiscriminate dumping and dumping inside river.

(3) These methods adopted by the rural dwellers expose them to increased risk of infection and diseases.

(4) Possibilities abound that the rural inhabitants may not have optimal health as a result of improper waste disposal.

\section{Recommendations:-}

(1) Rural health extension workers should increase their enlightenment of the inhabitants on the need for proper and suitable waste disposal methods.

(2) Supervision and enforcement of the monthly environmental sanitation exercises in the country should be extended to the rural areas. 


\section{References:-}

1. Akinsola, S.A. (2006). A-Z of community health in medical nursing and health education practice. Ibadan: College Press.

2. Ani, N.R and Ezeugwu, J.A.(2014).Barriers to meeting the primary health care information needs of rural women in Enugu State Nigeria, West Africa.www.iiste.org vol.X,NoX

3. Ani, N.R. and Ugwuoke, A.C. (2015).Provision of human waste disposal facilities in Nkanu West Local Government Area of Enugu State. Nigerian journal of Health Promotion,8.320-334

4. Basvanthappa, B.T.(2008).Community Health Nursing. $2^{\text {nd }}$ Edition. New Delhi, India.Jaypee brothers medical publishers

5. Ezedum, C.E. (2002). Appropriate health education strategy for achieving rural water supply and sanitation development in Nigeria. Evidence from a rural Nigerian Community. Journal of Health Education and Sports Science, 3(1), 1-7.

6. Hornby, A.S. (2001). Oxford advanced learners dictionary of current English. Oxford. Oxford University Press.

7. Lucas, A.O. and Gilles, H.M. (2009). Short textbook of public health medicine for the tropics. London. Book Power Pub.

8. NPC (2007). National Population Commission. Abuja.

9. Obionu, C.N. (2015). Synopsis of Occupational and Environmental Health. Enugu: Ezu Books

Ltd.

10. Otujo, C.O. and Awokoya, J. O. (2014). Assesment of solid waste management method in two food markets of Ijebu Ode Local Government Area Ogun State .Nigerian School Health Journal, 26, 2,109-114. 